\title{
Property rights to transport: regulatory issues
}

\author{
Nina Semeryanova ${ }^{1, *}$, Olga Fedorenko $^{1}$, and Anna Kopytova ${ }^{2}$ \\ ${ }^{1}$ South Ural State University (National Research University), Nizhnevartovsk Branch, Mira str., 9, \\ 628600, Russia \\ ${ }^{2}$ Tyumen Industrial University, Volodarskogo str., 38, Tyumen, 625000, Russia
}

\begin{abstract}
Applicability of the issue under research is preconditioned by the fact that Russian property right does not meet modern realities; lack of proper regulation raises practical problems of law enforcement and does not guarantee the stability of civil circulation in this area of legal relations. The purpose of the article is to actualize the problematic issues of property law, as the modernization of civil legislation cannot be completed without proper reforming of property right and other proprietary interests. The leading approach to research into this issue is the analysis of civil legislation, the Concept of the development of civil legislation and the draft of Russian Federal Law, which makes it possible to identify the problems of regulating property-legal relations and search for the possibilities for their subsequent resolution. The current usage of limited property rights is significantly difficult. That problem exists due to the lack of guaranteed protection of the owners' rights to other people's things. As a result, there are doubts in the possibility of realizing of the owners' rights without prejudice to their interests. The bearer of limited property rights must be sure of the correctness of his actions and the correct understanding of content of the norm. This is why the right to someone's things should be guaranteed. The completed analysis can contribute to the protection of the rights and interests of property owners and people owning other people's property on limited property rights.
\end{abstract}

\section{Introduction}

The reform of the civil legislation has been underway in Russia since 2013 in accordance with the accepted Concept of the civil legislation development (further - the Concept). Sections of the Civil Code of the Russian Federation (hereinafter referred to as the Civil code), regulating the Private International Law, provisions on the objects of civil rights, on legal entities, on the rights to the results of intellectual activity and means of individualization have been amended. In the near future, it is planned to complete reforming rules of liability law and begin modernization of the real right.

Paragraph 1 of Art. 2 of the Civil code defines a legal status of participants of civil turnover, grounds for the emergence and the procedure of exercising the property right and other real rights. The section II "Property right and other proprietary interests" covers about hundred articles where the content of the property right, as opposed to other real rights,

\footnotetext{
*Corresponding author: agt@ya.ru
} 
excels in obvious advantage. The existing system of real rights is being constantly criticized. In this regard, it is planned to amend the section "Property right and other proprietary interests" in compliance to the modern economic realities, focused on the rapprochement of the Russian legislation with the legislation of other legal systems of the civil law.

Property right and other real rights are included into the generic group of civil category "real rights" (Latin of jus in re(m); English proprietary interest, right in rem; French droit reel; German Realrecht), which is the subsector of civil law, including property interests and limited real rights. Therefore, the purpose of the Concept is creating a full-fledged system of limited real rights, renaming the section II into "The Property interest" and changing the structure and contents of this section. However, there is still no unity of views among legal experts concerning concept and indications of proprietary interest, construction of proprietary interests' system, their origin and reasons of termination (Emelkina, 2016).

\section{Methods}

Research of the proprietary interests has quite a long history and a rich methodology. The key scientific methods were used in the research: dialectics, abstracting, analysis, synthesis, generalization, deduction, formally legal method. The theoretical basis for the study was the norms of domestic and foreign legislation on proprietary rights, as well as the position of scientists on the problem of determining the scope of proprietary interests, their legal nature. (E. Sukhanov, A. Ivanov, R. Bevzenko, A. Rybalov). The comparatively legal method made it possible to correlate the Romano-German legal system and the AngloSaxon system of law in the sphere of regulation of property rights, to identify gaps and shortcomings in the Russian legislation on property rights, to conduct a study that would allow the adoption of positive foreign experience for improving domestic legislation. The dialectical method allowed studying deeply and fully the essence of property rights, their legal nature, to investigate issues that are contentious in doctrine, such as relations between co-owners, preferential rights and nature of corporate interests.

\section{Results}

3.1. The existing Civil code of the Russian Federation does not contain the concept "real right". The legislation of most foreign countries does not contain the definition of this concept either. In classical literature, the thing is defined both as philosophical and legal category. Philosophy regards the essence of things through the matter. Matter is the nature or infinite compatibility of things (Liebig, 1866, Bacon, 1977). The thing, as a legal category, occupies the central place in the system of civil law since the existence of the civil law in Ancient Rome. Things are objects of external material world both created by human labor and by nature.

The Civil Code of the Russian Federation regards things under the category of objects of civil rights. Things include money and securities. However, they are considered as a special sort of things by virtue of their specific connection with legal relationships of obligation. Being objects of civil rights, things form a basis of economic relations, focused on this thing, which can satisfy any human need.

In legal literature, real rights are considered in objective and subjective sense. The real right (in objective sense) is defined as a set of legal provisions, attributing possession for things (property) to subjects of real rights, regulating authorities of these subjects, concerning these things, and establishing responsibility for their violations. Real right (in subjective sense) is considered as the right of the specific subject to possession, use and 
disposition of this property (Bondarenko, 2009). The specification of actual relations, concerning possession and use of things, is performed by their subjects (Andreyev, 2007).

Chapter 2 of the Concept "General provisions on real rights" requires to determine real rights as subjective rights and to establish general rules for all real rights reflecting characteristics (properties) of any real right.

In this regard, Article 221 of Draft Federal Law No. 47538-6, approved in the second reading (further - the Draft Law), defines real right as direct dominance over the thing, provided to the person, and which serves as the basis for realization of legal authorities of possession, use and disposition, together or separately, and in the limits set by the Civil Code.

In spite of the fact that characteristics of real rights are not specified in the legislation (except for two: the absolute nature of the protection and resale royalty right - within the meaning of Article 216 and 305 of the Civil Code), they have emerged in the doctrine of the civil law and become the subject of study of real rights as a separate part of the academic course "Civil law". Characteristics of real rights include: a) indissoluble connection with a thing, "attachment" to it; a subject of this right is a material thing; b) the real right is characterized by specific contents, which is the direct domination over the property. Thus, the subject does not require any intermediation of the third parties for realization of the right. Different types of real rights are determined by various extent of domination over the thing, shown in a set of certain authorities, which is legal content of specific property right; c) definiteness of a legal way of acquisition of the real right, form and conditions for its validity are established by the legislation; d) absolute nature of real rights (Shchennikova, 2006).

The revised version of this Draft Federal Law has defined the following characteristics of real rights: a) real right directly burdens a thing and follows it. b) real rights do not have validity period unless otherwise specified by the Civil Code of the Russian Federation; c) in case of loss of possession for a thing, the real right continues; d) the real right is protected from violation by any person; e) real rights are those, which are established by the Civil code of the Russian Federation; e) subjects, objects, content of real rights, grounds for their emergence and termination and rules of their protection are established by the Civil code; e) exercise of real rights is regulated by the Civil code, or by other laws if provided by the Civil code) change of established rules, regarding exercise of real rights is allowed by agreement of parties in cases provided by the Civil code (Art. 221 of the Draft Federal Law).

It is essential to define characteristics of real rights in the Civil code, as it will allow to avoid confusion and to exclude chaotic search of characteristics of real rights in those places where they should not be. The definition of diagnosed characteristics of real rights will lead to easier delimitation of real rights from those of obligations and will allow recognizing proprietary nature of specific property interests.

3.2. Only individual, certain things and things determined by generic features in case of their individualization can constitute objects of real rights. This principle is approved by the legislation of a majority of countries. In case of acquisition of a set of things (as a part of a property complex, a set of goods, etc.) the real right to each thing arises. The property title transfer to another person does not serve as the ground for termination of other real rights for this property.

The same approaches are also reflected in the Draft Federal Law, which establishes that division or combination of things burdened with real rights does not result in the termination of these rights unless otherwise provided or specified by the law or by any relevant agreement. It also specifies that the division of the thing burdened with limited real right, including right of possession, in particular for the purpose of an apportionment in nature of the share in the common title to general property for this thing, is not allowed 
without the consent of the tenant of the limited real right (Art. 222 of the Draft Federal Law).

Classification of real rights has always been a matter of academic discussions. Roman law traditionally divided real rights into property, freedom (which was considered as the property right to one's own body), inheritance (as the right to a testator's all property rights), rights to other people's things and pledge. The system of medieval German law considered as the real right any possession, property, usufruct, pledge and different types of burgage rights. Russian pre-revolutionary law subdivided real rights into property, possession (hereditary, lifelong and urgent), the right of private participation and pledge (Big Law Dictionary, 2010).

In accordance with the existing Russian legislation real rights are divided into two groups: property rights and limited real rights. The property right is regarded as more comprehensive real right because it includes three authorities of the owner - possession, use and disposal. Limited real right represents rights to other people's thing, and therefore, has no such breadth of authorities as the property right. Any of the authorities (possession, use or disposal) is limited.

Modern foreign legislation defines a range of real rights in a different way. Research of proprietary rights is significant both in English and American legal theory as well. Some researchers scientists admit interconnection between contractual and proprietary rights, necessity to revise private and legal theory of the proprietary interests and contractual rights (Sjef van Erp (2013/14). A single object of real rights for all legal systems is a material thing. Rights to other people's things, as an object of real rights, are also provided by national legal systems of foreign countries. However, the range of real rights significantly differs in each country. For instance, German Civil Code allows for separate kinds of real rights concerning property interest, in particular, usufruct (1068-1084 German Civil Code). France, in contrast to Germany, allows for the right to be an object of real rights more widely in accordance with rules about pledge of debt claims, usufructs, easements, etc. (Art. 256, 2081, 2118, etc.). Austrian legislation provides for development right. English law regards rent of real estate as a kind of the property right, unlike Romano-Germanic law which considers it as the law of obligation (Vasiliev, Komarov, 2004). Similarly, English law regards trust property as real rights, whereas Romano-Germanic law refers it to the law of obligation (Ahmetyanova, 2014). The well-known examples are private easements "law of neighbouring tenements" or "real servitudes", which are widely applicable in legislations of foreign states.

Paragraph 1 of Article 216 of the Civil Code of the Russian Federation makes explicit mention of only some limited real rights, namely: right of lifetime inheritable possession for a land plot (Art. 265 of the Civil Code of the Russian Federation, Art. 21 of the Land code of the Russian Federation); right of (constant) unlimited use of the land plot (Art. 268 of the Civil Code of the Russian Federation, Art. 20 of the Land code of the Russian Federation); right of limited use of someone's land plot (easements of Art. 274, 277 of the Civil Code of the Russian Federation, Art. 23 of the Land code of the Russian Federation, Art. 9 of the Forest code of the Russian Federation); right of economic management (Art. 294 of the Civil Code of the Russian Federation); right for operational management (Art. 296 of the Civil Code of the Russian Federation). The list of real rights is established by the law and is rather exhaustive. However, as it is said above, real rights can also be found in other regulatory acts.

This situation is seriously criticized by law community. Thus, according to $\mathrm{R}$. Bevzenko, the Civil code of the Russian Federation lacks provisions on property rights, which would enable the participants of the turnover and owners of encumbered objects to build up reasonable and fair legal frameworks for economic cooperation. This "birth trauma" of the Civil Code of the Russian Federation can be explained by the fact that the 
first part of the Code was adopted in circumstances, when the Communist Party had the plurality in the State Duma. They blocked the introduction of the unencumbered private property title to land in Russia. Therefore, it became impossible to build up a classical framework of property rights (Bevzenko, 2016).

A. Rybalov does not quite agree with him. In his opinion, the national system of limited property rights is not characterized just by the Civil Code. This system draws upon a number of laws and court practice, which makes the system very dynamic (Rybalov, 2016). He notes that the right to lifetime inheritable estate is something between usufruct and emphyteusis. This right reflects Soviet realities but its content is quite traditional. Easement goes beyond the Civil Code. This includes both provisions of the Land Code of the Russian Federation on public land and separate laws which contain specific provisions on special easements. Housing Code of the Russian Federation considers the right to use dwelling premises as property right on the basis of the legate and on the basis of the contract of lifelong support and dependence. Town Planning Code, with the complicity of the Land Code, has vested us permanent right to use a land plot for construction and operation of a hired house, this could be considered a superficies Rybalov, 2016).

According to E.I. Samoilov, the right to use dwelling premises of former family members of the owner of privatized living quarters by its legal nature is also a limited real right, which is the right of permanent use of someone else's living quarters. It cannot be transferred to another person, follows the destiny of the quarters, and should be protected from violations by third parties, including the owner (Samoilov, 2013).

Whatever we think of the existing system of property rights, it has undoubtedly become obsolete. Modern circulation of limited real rights is much more complicated and this is due, primarily, to the lack of guaranteed protection of the owner's rights to the things of others, and consequently, growing doubts about the possibility of their implementation, without impending the interests. The holder of a limited real right must be confident of the correctness of his actions and, thus, of his correct understanding of the substance of the norm. Therefore, the right to someone else's thing must be guaranteed.

3.3 Article 223 of the Draft Law formalizes the following types of limited property rights in the Civil Code:

1) the right of permanent land ownership which is intended to regulate relations in the sphere of use of land for agriculture, forestry, fishery arrangements, fish farming, hunting, creating specially protected areas and geological features, as well as for other specified purposes prescribed by law, the achievement of which involves the use of natural properties and qualities of the land (emphyteusis);

2) building tenancy is the right of possession and use of someone else's land plot with a view to erecting a building or a facility on it and for its subsequent operation. A person entitled to building tenancy has the right to build on someone else's land one or more buildings and constructions, unless otherwise provided by the agreement on the establishment of development rights.

3) easement is a land plot, a building or a construction (a serving thing) may be encumbered with a right of limited use of the authorized person (easement) to exercise his ownership right to a land plot, a building or a construction, including construction in progress (a dominant thing) if the use of such a land plot, a building or a construction for intended purposes is impossible without easement. An easement cannot be established if it makes it impossible for the owner of the serving thing to use it according to its intended purpose or makes its use difficult so much that the serving thing loses its purpose. The following classification of easements is proposed: relocation easement, construction easement, the easement of land development, mining easement, municipal easement; 
4) usufruct is a limited real right when the owner of an immovable has the right to authorize another person - a citizen, and in the cases stipulated by law - a non-profit organization (usufructuary) the right of personal possession and use of this thing (usufruct);

5) mortgage - mortgagee, by virtue of the mortgage and in order to satisfy his claims at the expense of the mortgaged immovable, has the right to dispose of the mortgaged immovable in accordance and under conditions defined by law and the mortgage contract;

6) right to purchase someone's else immovable - a person has the exclusive right before other persons to acquisition of this thing for ownership. By the rules of the right to purchase someone's else immovable, it is possible to obtain mortgage or development rights in respect of someone else's immovable.

7) rent right is the right that gives its holder the possibility to receive periodically property advancement in the form of goods, money, work or services in a certain amount (volume) from the owner of the immovable. In case of non-receipt, he has the authority to levy execution upon this thing in accordance with the procedure prescribed for a mortgage.

8) the right of operational administration - when state-owned or municipal unitary enterprises and institutions possess, use and dispose of property belonging to them within the limits prescribed by law, in accordance with the objectives of their activities, assignment of the owner or the purpose of the property;

9) the right of limited land ownership - the owner of a building or a construction that has no other real right to a land plot or contract with the land owner, is entitled to own and use the land plot to the extent, needed to ensure the access to a specific building or a construction (the right of limited land ownership). The owner of a land plot has the right, unless otherwise provided by law, to require proportionate payment from the owner of a building or a construction for possession and use of the land (Art. 297.1 of the Draft Law).

\section{Discussion}

The need for normative regulation of propriety legal relations, the definition of the scope of propriety interests and their legal nature in modern Russian civil law is obvious. This will allow regulating in Russia the civil turnover of property rights. The conclusions drawn in the research can contribute to a more productive study of the category of propriety interests, e.g., in corporate legal relations and relations in the field of housing rights.

\section{Conclusion}

Thus, the Draft Law abolished some types of limited real rights such as the right of economic management (use and possession but not disposal) and the right of permanent (indefinite) use of a land plot. The only retained right is the right of operational management or the right to use state-owned and municipal property.

The issue about types of limited real rights becomes especially topical in the light of the forthcoming reform. According to V. K Andreyev and O.A. Serova, a number of proprietary interests should include the share (interest) right of participants (members) of a business entity (partnership) or a production cooperative. This share should be qualified as corporate property interest (Andreyev, 2007, Serova, 2011). R.R Ushnitsky shares the similar position and notes that the key to understanding the legal nature of the rights to participation in corporations is fixed in p. 3 of Art. 65.2 of the Civil Code, where the right of participation is formulated as an absolute right. The absolute right to participate in corporations needs to be recognized by the positive law and be legally protected. The legal way to protect this right should be fully similar to the legal mechanism of vindication but it must be a separate legal way of protection (Ushnitsky, 2016, Uryuzhnikova, 2006). 
As R. Bevzenko believes, in the absence of a developed system of property rights, the legal deficiency was substituted by law of obligations - a lease agreement (Bevzenko, 2016). He criticizes the existing situation, as long-term relationships, associated with significant financial investments, are regulated not by the real right, which is stable and provides significant legal protection of interests, but by lease agreements. By virtue of the principle of freedom of contracts, they may include provisions on the unilateral rejection of contracts by the will of the lessor, provisions on termination of the contract in case of breach of the rent payment, unilateral changes in the rental rates, etc. As a result, leases are easily terminated by courts. In addition, construction is only possible on the leased land, and the circumstances listed above lead to negative consequences for the developer, leaving him without any rights to land (Bevzenko, 2016).

Thus, the establishment of the development right in the Civil Code will give the holder of the right a stable and secured possibility to use a land plot being in another person's property for an extended period.

According to E. A Sukhanov, building tenancy, first of all, as opposed to the lease law, may be a subject of the pledge, which provides the possibility of bank lending when constructing the corresponding object (Sukhanov, 2016).

Thus, a number of modern scientists cover the problem: V.K. Andreev, R. Bevzenko, A.A. Ivanov, A. Rybalov, E.A. Sukhanov, etc. Despite differences among scientists' opinions concerning certain rights that could be referred to the category of proprietary rights, the expedience of their establishment and fixing in the Civil Code, is quite evident. This is chiefly due to the dynamics of development of civil relations in Russia. In this regard, it seems necessary to separate proprietary rights (real obligations) from laws of obligations for the purpose of forming a stable, uniform law enforcement practice. As A.A. Ivanov notes, "If the rights are absolute, the number of them is always limited (numerus clausus), and their content is clearly cut by the law. If the rights are relative, their set is random, and they can be made by the will of individuals. Mix of absolute and relative rights always disbalances the system" (Ivanov, 2017).

The Draft Law also has provisions for introduction of the possessory protection institute. Any owner is entitled to the right of ownership protection, irrespective of whether he has the right to possession, including ownership prerogative. Therefore, persons who are not the owners will be protected in cases provided by law as well. (Art. 215 of the Draft Law). Under present-day conditions, this introduction is quite justified, as it will enable to terminate attempts for detinue.

\section{Acknowledgement}

The work was supported by Act 211 of Government of the Russian Federation, contract No 02. A03. 21. 0011 .

\section{References}

1. Z.A. Ahmetyanova, Property Law textbook. (Kazan, Kazan University, 2014)

2. V. K. Andreyev, On the right of private property in Russia (Critical Essay) (Moscow, Wolters Kluver, 2007)

3. F. Bacon Essays in 2 volumes. (Moscow, Thought, 1977)

4. Big Law Dictionary (Moscow, Knizhny Mir, 2010)

5. N.L. Bondarenko Civil law (Minsk, TetraSistems, 2009) 
6. Civil law in 4 volumes. Proprietary interest. Law of succession. Exclusive rights. Personal non-property rights (Wolters Kluver, 2005)

7. I.A. Emelkina European Research Studies, XIX, 3, Part B. University of Piraeus, International Strategic Management Association, 170-186 (2016)

8. J. Liebig Francis Bacon and natural method. (St.Petersburg, Kukol-Yasnopolsky Printing house, 1866)

9. O.A. Serova Theoretical, methodological and practical problems of classification of legal entities of the modern civil law of Russia. ( Moscow, Yurist, 2011)

10. L.V. Shennikova Proprietary interests in civil law of Russia (Moscow, Yurist, 2006)

11. E.A. Sukhanov, Journal of the Russian Law, 4, 37-38 (2016)

12. The Civil Code of the Russian Federation (1) N 51-FL. Collection of the legislation of the Russian Federation. 1994. No. 32. Art. 3301. (1994)

13. The concept of development of the civil legislation of the Russian Federation (approved by the Presidential Council for Codification and Enhancement of Civil Legislation 7 October 2009).

14. URL: http://arbitr.ru/presscentr/news/44088.html (site of Supreme Arbitration Court of the Russian Federation).

15. E.A. Vasiliev, A.S. Komarov Civil and commercial law of foreign countries. (Moscow, Mezhdunarodniye otnosheniya, 2004) 